\title{
Damla sulama uygulamalarının ayçiçeğinin su kullanımı, vejetatif gelişme ve verim parametrelerine etkileri
}

\section{The effects of drip irrigation applications on sunflower water use, vegetative growth and yield parameters}

\author{
Buse SALBAŞĐ, Tolga ERDEM(i) \\ Tekirdağ Namık Kemal Üniversitesi, Ziraat Fakültesi, Biyosistem Mühendisliği Bölümü, 59030, Tekirdağ \\ Sorumlu yazar (Corresponding author): T. Erdem, e-posta (e-mail): terdem@nku.edu.tr \\ Yazar(lar) e-posta (Authore-mail): buse.salbas@gmail.com
}

\section{MAKALE BİLGİSİ}

Alınış tarihi 04 Mayıs 2020

Düzeltilme tarihi 16 Mayis 2020

Kabul tarihi 20 Mayıs 2020

\section{Anahtar Kelimeler:}

Bitki su tüketimi

Su kullanım randımanı (WUE)

Dane verimi

\begin{abstract}
ÖZ Bu çalışmmada Trakya Bölgesi koşullarında farklı damla sulama uygulamalarının ayçiçeği bitkisinin su
kullanımı ile verim ve gelişme parametrelerine etkisi araştırılmıştır. Araştırmada, 7 gün sulama aralığında A sınıfı buharlaşma kabından ölçülen buharlaşma değerlerinin $\% 0,25,50,75,100$ ve 125 'inin uygulandığ altı farklı sulama suyu uygulaması gerçekleștirilmiștir. Araștırmanın ilk yılında tüm deneme konularına 7 kez sulama uygulaması ile birlikte 67.0 ile $334.8 \mathrm{~mm}$ arasında, denemenin ikinci yılında ise $12 \mathrm{kez}$ sulama uygulaması ile birlikte 133.6 ile $668.1 \mathrm{~mm}$ arasında sulama suyu uygulanmıştır. Araştırma sonucunda, deneme konularında bitki büyüme mevsimi boyunca ölçülen bitki su tüketimi değerleri 2018 yılında 375.2 ile $655.0 \mathrm{~mm}, 2019$ yılında ise 278.2 ile $801.3 \mathrm{~mm}$ arasında uygulanan sulama suyu miktarlarına bağl olarak değissmiștir. Deneme konularından elde edilen dane verimleri denemenin ilk y1lında $272.88 \mathrm{~kg} \mathrm{da}^{-1} \mathrm{ile}$ $503.73 \mathrm{~kg} \mathrm{da}^{-1}$ arasında, denemenin ikinci yılında ise $222.49 \mathrm{~kg} \mathrm{da}^{-1}$ ile $518.61 \mathrm{~kg} \mathrm{da}^{-1}$ arasında değișmiștir. Ayrıca, istatistikler analizler sonucunda farklı sulama uygulamalarının vejetatif gelişme ve verim parametrelerini etkilemediği sonucuna ulaşılmıştır. Her iki yılda da deneme konularından elde edilen dane verimleri toprağa giren su miktarına (yağıș + sulama) bağlı olarak değișmiștir. Araștırma sonucunda, su kaynaklarının yeterli olması ve damla sulama yönteminin uygulandığı koșullarda 7 gün sulama aralığından A sınıfı buharlaşma kabından ölçülen açık su yüzeyi buharlaşma miktarının $\% 100$ ve 125 'inin uygulanmas önerilebilir. Diğer yandan su kaynağının kısıtlı olduğu koşullarda yüksek IWUE ve WUE değerleri dikkate alınarak A sınıfı buharlaşma kabından ölçülen açık su yüzeyi buharlaşma miktarının \%25 ve 50'sinin uygulanması önerilebilir.
\end{abstract}

\section{ARTICLE INFO}

Received 04 May 2020

Received in revised form 16 May 2020

Accepted 20 May 2020

\section{Keywords:}

Evapotranspiration

Water use efficiency (WUE)

Seed yield

\section{ABSTRACT}

In this study, effects of different amount of irrigation applications on water use, yield and yield parameters of sunflower plant in Thrace Region conditions were investigated. The six different irrigation water amounts with 7 days interval applied based on a ratio of Class A pan evaporation as $0,25,50,75,100$ and $125 \%$ were created in the research. In the first year of the study, irrigation water was applied to all experimental subjects between 67.0 and $334.8 \mathrm{~mm}$ with 7 irrigation applications and 133.7 to $668.1 \mathrm{~mm}$ with 12 irrigation applications in the second year of the experiment. As a result of the research, the evapotranspiration values measured in the experimental subjects during the plant growing season changed depending on the amount of irrigation water applied between 375.2 and $655.0 \mathrm{~mm}$ in 2018 and between 278.2 and $801.3 \mathrm{~mm}$ in 2019. The sunflower seed yields obtained from the experiment subjects ranged between $272.88 \mathrm{~kg} \mathrm{da}^{-1}$ and $503.73 \mathrm{~kg} \mathrm{da}^{-1}$ in the first year of the experiment and $222.49 \mathrm{~kg} \mathrm{da}^{-1}$ to $518.61 \mathrm{~kg} \mathrm{da}^{-1}$ in the second year of the experiment. In addition, as a result of statistical analyses, it was concluded that different irrigation applications do not affect vegetative growth and yield parameters. The seed yields obtained from treatments in both years changed depending on the amount of water entering the soil (precipitation + irrigation). As a result of the research, it can be suggested to apply $100 \%$ and $125 \%$ of the evaporation measured from the Class A pan in 7 days irrigation interval under conditions where the water resources are sufficient and the drip irrigation method is applied. On the other hand, considering the high IWUE and WUE values in conditions where the water supply is limited, it may be recommended to apply 25 and $50 \%$ of the evaporation measured from the Class A pan. 


\section{Giriş}

Dünya nüfusunun hızlı artışı, insanların gıda ihtiyacını yakın gelecekteki en önemli sorun olarak karşımıza çıarmaktadır. $\mathrm{Bu}$ sorunun temel nedeni artan nüfus, sanayileşme ve kentleşme nedeniyle azalan tarım alanları ile küresel iklim değişikliğine bağlı olarak artan kuraklıktır. Küresel su tüketiminin en yoğun olduğu sektör tarım sektörü olduğundan kuraklığın etkileri de genellikle ilk olarak tarımda görülmekte ve yavaş yavaş diğer suya bağımlı sektörlere yayılmaktadır. Tarım sektöründe kuraklığın anlamı, diğer sektörlerden daha farklıdır. Çünkü bitkiler için yıl içerisinde yağan toplam yağıştan çok, büyüme dönemlerinde bitki kök bölgesinde var olan nem miktarı daha önemlidir. Dolayısı ile bitkilerin çıkıș ve gelișme döneminde ihtiyaç duydukları suyun toprakta bulunmamas1, tarımsal kuraklık olarak adlandırılmaktadır (Kapluhan 2013). Tarımsal kuraklığın, üretimdeki en önemli etkileri verimde miktar ve kalite açısından azalmalar, hastalık ve zararlıların artışı, ürün kayıplarının artması, hayvanc1lıkta üreme döngüsünün değişmesi, yemin ürüne dönüşüm oranın gerilemesi şeklinde sıralanabilir (Gürbüz 2011). Su kaynaklarının geliştirilmesi çalışmaları içerisinde sulama, diğer tarımsal girdilerin etkinliğini artıran, bitkisel üretimde kararlılığı sağlayan ve çağdaş tarımın ayrılmaz parçası olan bir bitkisel üretim ögesidir (Korukçu ve Yıldırım 1981).

Her bölgemizde yetişebilen, tanelerinde yüksek oranda ve kaliteli yağ içeren ayçiçeği, ülkemizde yağ bitkileri ekim alanında pamuktan sonra ikinci sırayı almaktadır. Geniş bir adaptasyon kabiliyeti olması ve ekimden hasada, fazla bir işgücü gerektirmemesi nedeniyle, ekim alanlarının \%75.9'u ile başta Trakya-Marmara bölgesi olmak üzere, Orta Anadolu, Karadeniz, Ege gibi birçok bölgemizde yetiştirilmektedir. Ayçiçeği ülkemizde genellikle güçlü kök sistemi nedeniyle kurağa dayanıklı olarak bilinmekte ve kuru koşullarda yetiştirildiğinden, hüküm süren olumsuz iklim koşulları ayçiçeği verimini önemli ölçüde etkilemektedir. Son yıllarda bu dönemdeki yağışların düzensiz olması tablanın küçülmesine, özellikle dane olum devresindeki aşırı sıcaklar tabladaki dane sayısının azalmasına, dane verimini ve yağ oranını düşürüp kabuk oranını arttırarak, birim alandan alınan yă verimini önemli ölçüde azalmasına sebep olmaktadır. Erdem (2000), Tekirdağ koşullarında karık sulama yöntemiyle sulanan ayçiçeği bitkisinin tüm büyüme sezonu boyunca su ihtiyacının karşılanması durumunda dane verimini $514 \mathrm{~kg} \mathrm{da}^{-1}$ olarak elde etmiştir. Ayrıca bitki büyüme periyotları içerisinde su kısıdına en hassas büyüme periyodunun çiçeklenme periyodu olduğunu bildirmiştir.

Trakya Bölgesinde, su kaynaklarının kısıtlı olması, son yıllarda hızlı ve plansız gelişen sanayinin bu mevcut kaynakları her geçen gün daha fazla tehdit etmesi tarımsal sulamada kullanılacak su miktarını kısıtlamaktadır. Trakya Bölgesinde iyi mekanizasyon, bilinçli gübreleme, etkin tarımsal mücadele, iyi tohumluk seçimi gibi etmenlerin yarattığ 1 verim artışı bir noktada kalmış ve bu da yetersiz olmaya başlamıştır. Yörede ulaşılan üretim değerlerini daha fazla arttırmanın yolu, bilinçli ve ekonomik sulama uygulamaları ile sulu tarım alanlarının ve suyun etkinliğini artıracak alternatif tarım girdilerinin hayata geçirilmesidir. Fakat günümüze kadar uygulanan bilinçsiz sulamalar ve mevcut suyun tarım dışındaki diğer alanlarda kullanımının artması nedeniyle sulama için kullanılacak su miktarında da azalmalar başlamıştır. Böylece, dünyada ve ülkemizde, mevcut kısitlı su ile birim alandan elde edilecek verimin artırılmasına yönelik çalışmalara hızlı bir şekilde yönelim başlamıştır. Sulama yöntemleri içerisinde, damla sulama yöntemi; yüksek randıman, üniform su kullanımı ve işletme kolaylığı bakımından, özellikle sebze ve meyve ağaçlarının sulanmasında ön plana çıkmaktadır.

$\mathrm{Bu}$ çalışmada ayçiçeği bitkisinde sulama uygulamalarının oldukça yeni olduğu Trakya Bölgesinde, damla sulama uygulamalarının bitkinin su kullanımı ile verim parametrelerine olan etkisi araştırılmıştır. Araştırma, Tekirdağ Bağcılık Araştırma Enstitüsü arazisinde 2018 ve 2019 ayçiçeği yetiştirme sezonlarında yürütülmüştür. Elde edilen verilerin ayçiçeği üreticilerine ve bölgedeki su kaynakları planlayıcılarına faydalı olacağı düşünülmektedir.

\section{Materyal ve Yöntem}

Araştırmanın yürütüldüğü alan yarı kurak bir iklim kuşağı içinde yer almaktadır. Deneme alanında 2018 ve 2019 yıllarında ayçiçeği büyüme mevsimi sıcaklıkların Mayıs ayının son haftasından itibaren $20.0^{\circ} \mathrm{C}$ 'nin üzerine çıkmaya başladığ bitkinin hasat edildiği tarihe kadar ortalama $25.0^{\circ} \mathrm{C}$ civarlarında seyrettiği görülmüştür. Bitki büyüme mevsimi boyunca ölçülen yağış değerleri 2018 yılında 190.5 mm olarak kaydedilmiştir. Özellikle 28 Haziran, 24 Temmuz ve 30 Temmuz tarihlerinde bölge koşullarında uzun yıllardır gözlenmeyen yağış değerleri kaydedilmiştir. Denemenin ikinci yılında ise yağış değerleri haricinde 2018 yılına göre benzer değerlerin ölçüldüğü görülmüştür. Sıcaklık değerleri aynı şekilde Mayıs ayının son haftasında artmaya başlamış ve tüm büyüme mevsimi boyunca ortalama olarak $25.0^{\circ} \mathrm{C}$ civarlarında ölçülmüştür. Denemenin ikinci yılında yağış değerleri ise tüm büyüme mevsimi boyunca $57.5 \mathrm{~mm}$ olarak ölçülmüştür. Özellikle denemenin ilk yılında yüksek yağış değerlerinin ölçülmesi sulama uygulamaları ve bitki su tüketimi ölçümlerini önemli ölçüde etkilemiştir.

Araştırma alanında iki farklı profilden alınan toprakların; tarla kapasitesi, solma noktası, bünye sınıfı, hacim ağırlığı ve kullanılabilir su tutma kapasitesi değerlerine ilişkin veriler Çizelge 1'de sunulmuştur. Araştırma alanının toprak bünye sınıfı kil veya killi-tın, kullanılabilir su tutma kapasitesi 2018 ve 2019 yıllarında $90 \mathrm{~cm}$ toprak derinliği için sırasıyla $152.38 \mathrm{~mm}$ ve $128.17 \mathrm{~mm}$ olarak hesaplanmıştır. Çift silindir infiltrometre ölçmeleri sonucunda toprağın sabitleşen infiltrasyon hızı 20 $\mathrm{mm} \mathrm{h}^{-1}$ olarak bulunmuştur. Sulama suyu kalite sınıfi $\mathrm{T}_{2} \mathrm{~S}_{1}$ 'dir.

Araştırmada bitkisel materyal olarak Syngenta firması tarafindan üretilen Sanay MR ayçiçeği (Helianthus annuus L.) tohumu kullanılmıştır. Kullanılan çeşit, kuraklığa toleranslı, her türlü toprağa uyum kabiliyeti yüksek, mildiyö (köse) hastalığına toleransl1, ayçiçeğinin en önemli paraziti olan orobanşa dayanıklıdır.

Araştırma, tesadüf bloklarında deneme deseninde üç tekerrürlü olarak yürütülmüştür (Yurtsever 1984). Araştırmada deneme konuları ortalama 7 gün sulama aralığında A sınıfi buharlaşma kabından ölçülen açık su yüzeyi buharlaşma miktarının \%0 ( $\left.\mathrm{I}_{1}\right), \% 25\left(\mathrm{I}_{2}\right), \% 50\left(\mathrm{I}_{3}\right), \% 75\left(\mathrm{I}_{4}\right), \% 100\left(\mathrm{I}_{5}\right)$ ve $\% 125\left(\mathrm{I}_{6}\right)$ uygulanmas1 şeklinde oluşturulmuştur.

Deneme alanı $18.60 \times 51.00 \mathrm{~m}$ boyutlarında olup toplam $948.60 \mathrm{~m}^{2}$ 'dir. Oluşturulan 3 bloğun her birinde 6 adet olmak üzere toplam 18 adet parsel bulunmaktadır. Bir deneme parseli $4.20 \times 6.00 \mathrm{~m}$ boyutlarında olmak üzere toplam $25.20 \mathrm{~m}^{2}$ alana sahiptir. Bir deneme parselinde 6 adet bitki siras1 bulunmaktadır. Bitkiler, 2018 yılında 27 Nisan ve 2019 yılında 30 Nisan tarihlerinde sira aralığ $0.70 \mathrm{~m}$ sira üzeri ise $0.30 \mathrm{~m}$ olacak şekilde deneme parsellerine ekilmiştir. Tüm parsellerde birer bitki sırası kenar etkisi göz önüne alınarak hasat parseli dışında bırakılmıştır. Böylece hasat parseli $2.80 \times 4.80 \mathrm{~m}$ olmak 
Çizelge 1. Araştırma alanı topraklarının fiziksel özellikleri.

Table 1. The physical characteristics of soil at the experimental site.

\begin{tabular}{|c|c|c|c|c|c|c|c|c|}
\hline \multirow{2}{*}{ Y1l } & \multirow{2}{*}{ Profil Derinliği $(\mathrm{cm})$} & \multirow{2}{*}{ Bünye sınıfı } & \multicolumn{2}{|c|}{ Tarla kapasitesi } & \multicolumn{2}{|c|}{ Solma noktas 1} & \multirow{2}{*}{$\begin{array}{l}\text { Hacim Ağgrlığ } \\
\left(\mathrm{g} \mathrm{cm}^{-3}\right)\end{array}$} & \multirow{2}{*}{$\begin{array}{l}\text { Kullanılabilir su tutma } \\
\text { kapasitesi (mm) }\end{array}$} \\
\hline & & & $\%$ & $\mathrm{~mm}$ & $\%$ & $\mathrm{~mm}$ & & \\
\hline \multirow{4}{*}{2018} & $0-30$ & Kil & 21.73 & 104.30 & 10.28 & 49.34 & 1.60 & 54.96 \\
\hline & $30-60$ & Kil & 22.54 & 107.52 & 11.88 & 56.67 & 1.59 & 50.85 \\
\hline & $60-90$ & Killi-tın & 19.60 & 90.55 & 9.52 & 43.98 & 1.54 & 46.57 \\
\hline & $0-90$ & & & 302.37 & & 149.99 & & 152.38 \\
\hline \multirow{4}{*}{2019} & $0-30$ & Kil & 23.01 & 102.86 & 15.91 & 71.12 & 1.49 & 31.74 \\
\hline & $30-60$ & Kil & 27.05 & 128.22 & 17.71 & 83.95 & 1.58 & 44.27 \\
\hline & $60-90$ & Kil & 31.76 & 153.40 & 20.96 & 101.24 & 1.61 & 52.16 \\
\hline & $0-90$ & & & 384.48 & & 256.31 & & 128.17 \\
\hline
\end{tabular}

üzere toplam $11.20 \mathrm{~m}^{2}$ olmuştur. Her deneme parselindeki bitki sayıs1 120 hasat parselinde ise 64 adettir. Parsellerin düzenlenmesi sırasında, sulamalarda sızma yoluyla oluşabilecek yan etkileri önlemek amaciyla parseller arasında ve bloklar arasında $3.00 \mathrm{~m}$ boşluk bırakılmıştır.

Her bir deneme parseli için manifold boru hatları $32 \mathrm{~mm}$ dış çaplı yumuşak PE borulardan oluşturulmuştur. Deneme parselleri içerisinde $16 \mathrm{~mm}$ dış çaplı yumuşak PE borulardan oluşan lateral boru hatları, her iki bitki sıra arasına bir hat olacak şekilde döşenmiştir. Damlatıcı debisi Yıldırım (2008)'de belirtilen esaslara göre toprağın bünyesi ve su alma hızı dikkate alınarak $4 \mathrm{~L} \mathrm{~h}^{-1}$ olarak seçilmiştir. Damlatıcı aralığı toprağın infiltrasyon hızı ve damlatıcı debisi dikkate alınarak $45 \mathrm{~cm}$ olarak hesaplanmıştır. Böylelikle her lateral boru hattına $50 \mathrm{~cm}$ aralıklarla in-line damlatıcılar kullanılmıştır.

Deneme parsellerinde uygulanacak sulama suyu miktarları aşağıdaki eşitlik yardımıyla 7 günlük yığışımlı açık su yüzeyi buharlaşma değerleri kullanılarak hesaplanmıştır (Kanber ve ark. 2004).

$$
I=K_{c p} \times E_{p} \times P
$$

Eşitlikte; I: uygulanacak sulama suyu miktarı $(\mathrm{mm}), \mathrm{K}_{\mathrm{cp}}$ : buharlaşma kabına bağlı katsayı, $\mathrm{E}_{\mathrm{p}}$ : yı̆̆ış̧ımlı buharlaşma miktarı $(\mathrm{mm})$, P: lateral aralığı ve damlatıcı aralığına göre belirlenen 1slatılan alan yüzdesi (\%)'dir. Islatılan alan yüzdesi damlatıcı aralığı ve lateral aralığına göre \%36 olarak hesaplanmıştır.

Bitki su tüketimi değerleri, aşağıda verilen su bütçesi yaklaşımı ile hesaplanmıştır (Walker ve Skogerboe 1987). Bu amaçla, her sulama öncesinde etkili bitki kök derinliğindeki (90 $\mathrm{cm})$ toprak nemi gravimetrik yöntemle belirlenmiştir.

$$
E T=I+P+C_{p}-D_{p} \mp R_{f} \mp \Delta S
$$

Eşitlikte; ET: bitki su tüketimi (mm), I: periyot boyunca uygulanan sulama suyu miktarı $(\mathrm{mm})$, P: periyot boyunca düşen yağış (mm), Cp: kök bölgesine kılcal yükselişle giren su miktarı $(\mathrm{mm})$, Dp: derine sizma kayıları (mm), Rf: deneme parsellerine giren ve çıkan yüzey akış miktarı (mm), DS: kök bölgesindeki toprak nemindeki değişimler $(\mathrm{mm})$, değerlerini göstermektedir.

Çalışma alanında taban suyu problemi bulunmadığından, bitki kök bölgesine kılcal hareketle su girişi olmadığ varsayılarak $\mathrm{Cp}$ değeri göz önüne alınmamıştır. Ayrıca, yüzey akış miktarları basınçlı sulama sistemi kullanıldığından hesaplara katılmamıştır (Kanber 1997). Derine sızma kayıpları için bir alt katman izlenmiştir.
Araştırmada deneme konularından elde edilen verim ve su tüketimleri arasındaki ilişkiler Stewart modeli esas alınarak aşağıdaki eşitlik yardımıyla belirlenmiştir (Doorenbos ve Kassam 1979).

$$
\left(1-\frac{Y_{a}}{Y_{m}}\right)=k_{y}\left(1-\frac{E T_{a}}{E T_{m}}\right)
$$

Eşitlikte; $\mathrm{Y}_{\mathrm{a}}$ : gerçek verim $\left(\mathrm{kg} \mathrm{da}^{-1}\right), \mathrm{Y}_{\mathrm{m}}$ : maksimum verim $\left(\mathrm{kg} \mathrm{da}^{-1}\right)$, ky: su- verim ilişkisi faktörü, ETa: gerçek bitki su tüketimi $(\mathrm{mm}), \mathrm{ET}_{\mathrm{m}}$ : gerçek bitki su tüketimi $(\mathrm{mm})$ değerlerini göstermektedir.

Deneme konularına uygulanan sulama suyu, ölçülen bitki su tüketimi ve hasat verimlerine göre, sulama suyu ve su kullanım randımanı değerleri dane veriminin mevsimlik ET'ye ve toplam uygulanan sulama suyu miktarına bölünmesiyle hesaplanmıştır (Zhang ve ark. 1999).

Her bir deneme parselinde hasat işlemleri 2018 yılında 4 Eylül, 2019 yılında ise 5 Eylül tarihlerinde sonlandırılmıştır. Her bir deneme parseli içerisindeki ölçüm alanında bulunan bitkilerden bitki boyu, bitki gövde çapı kalınlığı, tabla çapı, dane verimi, bin dane ve hektolitre ağırlıkları, kuru madde miktarı, yağ oranı değerleri belirlenmiş̧ir. Deneme konularından elde edilen ayçiçeği gelişim ve verim parametreleri arasındaki farklılıkların düzeyinin belirlenmesinde varyans analizi, farklılıkların sinıflandırılmasında ise LSD testi kullanılmıştır. Elde edilen veriler Yurtsever (1984)'de açıklanan esaslara göre değerlendirilmiştir.

\section{Bulgular}

Deneme konularına 7 gün ara ile denemenin ilk yılda 7, ikinci yılında ise $12 \mathrm{kez}$ sulama uygulaması yapılmıştır. Uygulanan toplam sulama suyu miktarları, 2018 y1lında deneme konularına göre 67.0 ile $334.8 \mathrm{~mm}$ arasında, 2019 yılında ise 133.7 ile $668.1 \mathrm{~mm}$ arasında değişmiştir. Araştırmada sulama uygulamalarının 7 gün aralığında yapılması planlanmasına karşın, 2018 yılında 28 Haziran'da 50.5 mm, 24 Temmuz'da $28.2 \mathrm{~mm}$ ve 30 Temmuz'da 29.9 mm'lik mevsim normallerine göre fazla yağışın düşmesi sulama uygulamalarını etkilemiş̧ir. Böylelikle, tüm büyüme mevsimi boyunca düşen toplam yağış miktarlar1 2018 yilında $190.5 \mathrm{~mm}$ olurken, 2019 y1lında bu değer $57.5 \mathrm{~mm}$ olmuştur. İki deneme yılının toplam yağış miktarları arasındaki fark, 2018 yılında uygulanan toplam sulama suyu sayılarının ve miktarlarının 2019 yılına göre daha düşük olmasına neden olmuştur.

Her bir deneme konusunda sulama uygulamaları öncesinde $90 \mathrm{~cm}$ toprak derinliğinde ölçülen nem değerleri 2018 yılı için Şekil 1'de ve 2019 yılı için Şekil 2'de verilmiştir. Şekillerden 
görüleceği gibi uygulanan sulama suyuna bağlı olarak ölçülen nem miktarlarında azalış daha fazla olmuştur. Denemenin ilk yılında aşırı yağışlardan dolayı sulama öncesi nem değerleri farklılıklar göstermiştir. Denemenin ikinci yılında ise A sınıfı buharlaşma kabından ölçülen buharlaşma miktarının \%100'ün uygulandığ $\mathrm{I}_{5}$ deneme konusunda sulama sezonu öncesinde ölçülen toprak nem değerlerinin ortalama olarak kullanılabilir su tutma kapasitesinin \%60'1 seviyelerinde olduğu belirlenmiştir. Özellikle 2019 yılında sulama suyu uygulanmayan $\left(\mathrm{I}_{1}\right)$ ve buharlaşma miktarının \%25'i uygulanan $\mathrm{I}_{2}$ deneme konularında sulama öncesi mevcut nemlerinin solma noktası ve altındaki seviyelere düştüğü görülmüştür.

Tüm deneme konularında 2018 ve 2019 yılı yetiştiricilik dönemleri içerisinde uygulanan sulama suyu miktarları, etkili yağış ve topraktaki nem değişimi değerlerine göre hesaplanan bitki su tüketimi değerleri Çizelge 2'de özetlenmiştir. Toplam büyüme mevsimi boyunca deneme konularından ölçülen bitki su tüketimi değerleri 2018 y1lı için $375.2 \mathrm{~mm}$ ile $655.0 \mathrm{~mm}$ arasında, 2019 yılı için $278.2 \mathrm{~mm}$ ile $801.3 \mathrm{~mm}$ arasında değişmiştir. Mevsimlik toplam bitki su tüketimi değerleri tüm büyüme mevsimi boyunca uygulanan su miktarı arttıkça artmıştır. Denemenin birinci yılında aşırı yağıș miktarları, ikinci yılında ise yüksek sulama suyu miktarları bitki su tüketimi değerlerini etkilemiştir. Deneme konularından $\mathrm{I}_{1}, \mathrm{I}_{2}$ ve $\mathrm{I}_{3}$ 'de ölçülen mevsimlik bitki su tüketimleri aşırı yağıştan dolayı 2018 yılından daha yüksek olmuştur. Diğer yandan, I4, I5 ve I6 deneme konularında ise ölçülen mevsimlik bitki su tüketimi değerleri ise daha fazla sulama suyu uygulamasından dolayı 2019 yılında daha yüksek olmuştur. Bu çalışmadan elde edilen ayçiçeği bitkisi toplam mevsimlik bitki su tüketimi değerleri bölgemizde, ülkemizde ve dünyada yapılan daha önceki çalışmalardan elde edilen değerler ile paralellik göstermektedir (Erdem 2000; Demir ve ark. 2006; Karam ve ark. 2007; Sezen ve ark. 2011; Yavuz 2016; Swain ve ark. 2019).

Ayçiçeği bitkisinin vejetatif gelişme unsurları olarak; bitki boyu, sap kalınlığı ve tabla çapı değerleri değerlendirilmiştir. Yapılan istatistik analizler sonucunda farklı sulama uygulamalarının vejetatif gelişme unsurlarını etkilemediği sonucuna ulaşılmıştır. Verim ve kalite unsurları olarak, bin dane ağırlığ 1 , hektolitre ağırlığı, kuru madde miktarı ve yağ içeriği değerleri incelenmiştir. $\mathrm{Bu}$ değerlere göre yapılan analizler sonucunda, bin dane ağırlı̆̆ değerlerinin ikinci yıl sonuçları hariç deneme konularından elde edilen değerler arasında istatistiksel olarak önemli farklar elde edilmemiştir. $\mathrm{Bu}$ değerlere ilişkin veriler Çizelge 3'de özetlenmiştir. Deneme konularından elde edilen dane verimleri Çizelge 4'de verilmiştir. Elde edilen dane verimi değeri 2018 yılında 272.88 $\mathrm{kg} \mathrm{da}^{-1}$ ile $503.73 \mathrm{~kg} \mathrm{da}^{-1}$ arasında, denemenin ikinci yllında ise $222.49 \mathrm{~kg} \mathrm{da}^{-1}$ ile $518.61 \mathrm{~kg} \mathrm{da}^{-1}$ arasında değişmiştir. Her iki yılda da deneme konularından elde edilen dane verimleri uygulanan sulama suyuna ve düşen yağış miktarına bağlı olarak değişmiştir. Özellikle denemenin ilk yılında yağış miktarının fazla olması, sulama miktarının daha az olduğu $I_{2}, I_{3}$ ve $I_{4}$ deneme konularından ikinci yıla göre daha yüksek dane verimi elde edilmesine neden olmuştur. Diğer yandan, uygulanan sulama suyu miktarının daha fazla olduğu $I_{5}$ ve $I_{6}$ deneme konularında ise toprağa giren su miktarı daha fazla olduğundan birinci yıla göre daha fazla dane verimleri elde edilmiştir. Deneme süresince sulama suyu uygulanmayan $\mathrm{I}_{1}$ konusunda elde edilen ayçiçeği dane verimi değerleri 2018 y1lında ortalama olarak $272.88 \mathrm{~kg} \mathrm{da}^{-1}, 2019$ y1lında ise $222.49 \mathrm{~kg} \mathrm{da}^{-1}$ olmuştur. İki deneme yılı arasındaki fark büyüme mevsimi boyunca 2018 y1lında $190.5 \mathrm{~mm}, 2019$ yılında ise $57.5 \mathrm{~mm}$ olarak gerçekleşen yağış miktarlarıdır. Bölge ve ülke koşullarında daha önce yürütülen araştırmalarda da sulama suyu uygulanmadığı koşullarda elde edilen ayçiçeği dane verimlerinde de benzer sonuçlar elde edilmiştir. Erdem (2000) Tekirdağ koşullarında gerçekleştirdiği araştırmada, sulama suyu uygulanmayan koşullarda ayçiçeği dane verimini 254.41 ile 277.03 $\mathrm{kg} \mathrm{da}^{-1}$ olarak belirtmiştir. Benzer çalışmalarda, ayçiçeği dane verimi değerleri, Süllü ve Dağdelen (2013) tarafindan Söke koşullarında yürütülen araştırmada $231.40 \mathrm{~kg} \mathrm{da}^{-1} \mathrm{ve}$ Demir ve ark. (2006) tarafından Bursa koşullarında yürütülen araştırmada $216.0 \mathrm{~kg} \mathrm{da}^{-1}$ olarak elde edilmiştir. A sınıfi buharlaşma kabından ölçülen açık su yüzeyi buharlaşma değerinin \%100'ünün uygulandığ $\mathrm{I}_{5}$ deneme konusunda elde edilen dane

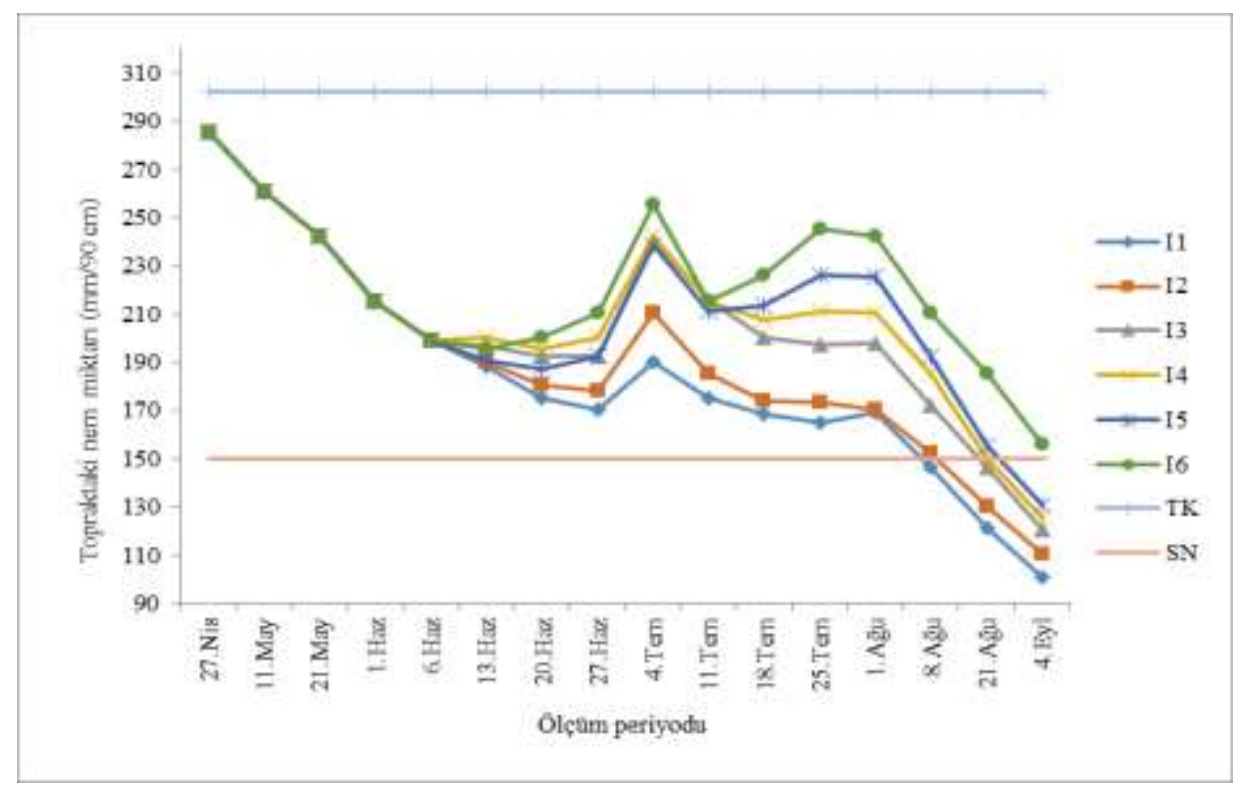

Şekil 1. Sulama uygulamaları öncesi topraktaki nem değişimleri (2018).

Figure 1. Moisture changes in the soil before irrigation applications (2018). 


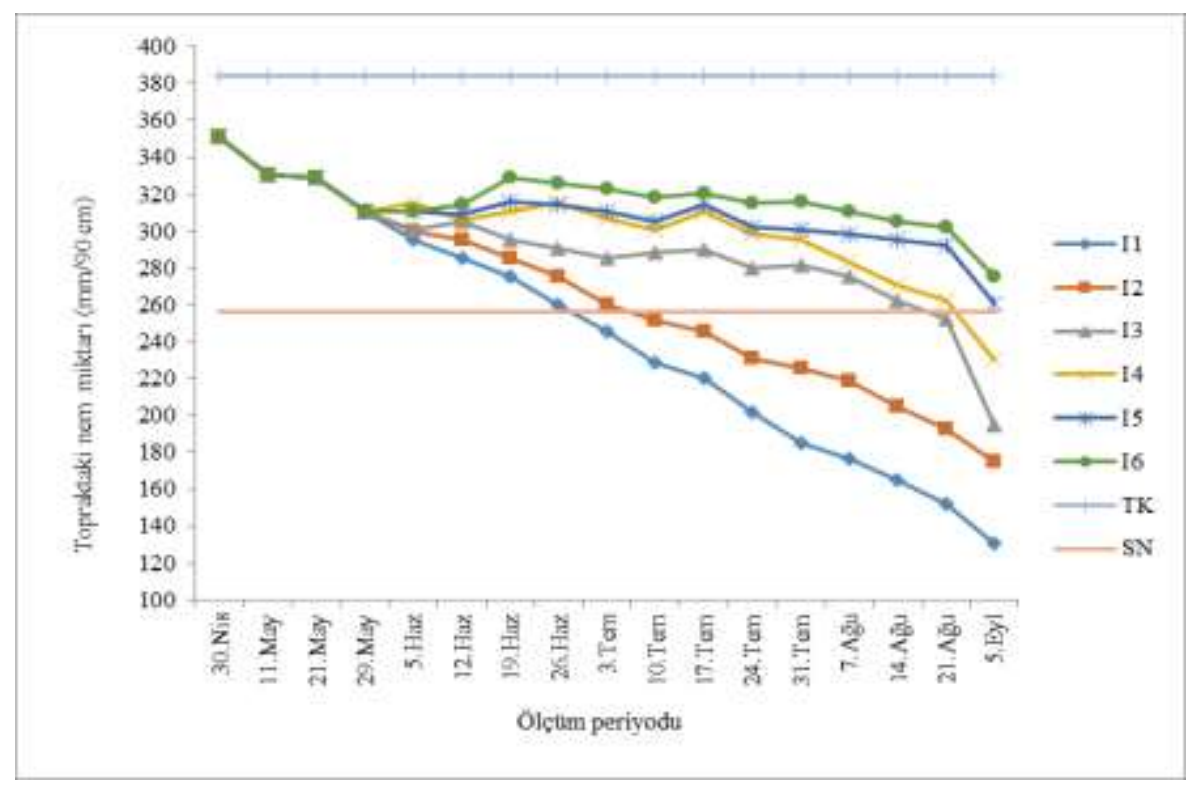

Şekil 2. Sulama uygulamaları öncesi topraktaki nem değişimleri (2019).

Figure 2. Moisture changes in the soil before irrigation applications (2019).

Çizelge 2. Deneme konularına uygulanan sulama suyu ve ölçülen bitki su tüketimi değerleri.

Table 2. Applied irrigation water and measured seasonal evapotranspiration for treatments.

\begin{tabular}{|c|c|c|c|c|c|}
\hline Deneme yılı & Deneme konusu & $\begin{array}{l}\text { Topraktaki nem değişimi } \\
(\mathrm{mm})\end{array}$ & $\begin{array}{l}\text { Yağış } \\
(\mathrm{mm})\end{array}$ & $\begin{array}{l}\text { Uygulanan toplam sulama } \\
\text { suyu miktarı }(\mathrm{mm})\end{array}$ & $\begin{array}{l}\text { Ölçülen mevsimlik bitki su } \\
\text { tüketimi }(\mathrm{mm})\end{array}$ \\
\hline \multirow{6}{*}{2018} & $\mathrm{I}_{1}$ & 184.7 & \multirow{6}{*}{190.5} & - & 375.2 \\
\hline & $\mathrm{I}_{2}$ & 175.1 & & 67.0 & 432.6 \\
\hline & $\mathrm{I}_{3}$ & 165.1 & & 134.1 & 489.7 \\
\hline & $\mathrm{I}_{4}$ & 160.2 & & 201.0 & 551.7 \\
\hline & $\mathrm{I}_{5}$ & 154.8 & & 267.8 & 613.1 \\
\hline & $\mathrm{I}_{6}$ & 129.7 & & 334.8 & 655.0 \\
\hline \multirow{6}{*}{2019} & $\mathrm{I}_{1}$ & 220.7 & \multirow{6}{*}{57.5} & - & 278.2 \\
\hline & $\mathrm{I}_{2}$ & 176.0 & & 133.7 & 367.2 \\
\hline & $\mathrm{I}_{3}$ & 156.0 & & 267.4 & 480.9 \\
\hline & $\mathrm{I}_{4}$ & 120.9 & & 401.1 & 579.5 \\
\hline & $\mathrm{I}_{5}$ & 90.7 & & 534.4 & 682.6 \\
\hline & $\mathrm{I}_{6}$ & 75.7 & & 668.1 & 801.3 \\
\hline
\end{tabular}

Çizelge 3. Deneme konularından ölçülen ayçiçeği vejetatif gelişme ve verim parametreleri değerleri.

Table 3. The measured sunflower vegetative growth and yield parameters for treatments.

\begin{tabular}{|c|c|c|c|c|c|c|c|c|}
\hline $\begin{array}{c}\text { Deneme } \\
\text { y1l1 }\end{array}$ & $\begin{array}{c}\text { Deneme } \\
\text { konusu }\end{array}$ & $\begin{array}{l}\text { Bitki boyu } \\
(\mathrm{cm})\end{array}$ & $\begin{array}{l}\text { Sap kalınlığ } 1 \\
(\mathrm{~cm})\end{array}$ & $\begin{array}{c}\text { Tabla çap1 } \\
(\mathrm{cm})\end{array}$ & $\begin{array}{l}\text { Bin dane } \\
\text { ağırlığ } 1(\mathrm{~g})\end{array}$ & $\begin{array}{l}\text { Hektolitre } \\
\text { ağırlığ } 1(\mathrm{~g})\end{array}$ & $\begin{array}{c}\text { Kuru madde } \\
\text { miktarı (\%) }\end{array}$ & $\begin{array}{c}\text { Yağ içeriği } \\
(\%)\end{array}$ \\
\hline \multirow{7}{*}{2018} & $\mathrm{I}_{1}$ & 182.05 & 2.53 & 14.74 & $76.27 \mathrm{c}^{*}$ & 46.70 & 94.13 & 41.17 \\
\hline & $\mathrm{I}_{2}$ & 179.62 & 2.48 & 15.64 & $80.03 \mathrm{bc}$ & 46.25 & 94.28 & 40.86 \\
\hline & $\mathrm{I}_{3}$ & 177.97 & 2.70 & 16.23 & $83.17 \mathrm{ab}$ & 45.34 & 94.04 & 39.23 \\
\hline & $\mathrm{I}_{4}$ & 181.53 & 2.45 & 16.24 & $78.27 \mathrm{bc}$ & 45.89 & 94.02 & 40.01 \\
\hline & $\mathrm{I}_{5}$ & 189.18 & 2.51 & 16.55 & $83.83 \mathrm{ab}$ & 46.45 & 94.04 & 39.26 \\
\hline & $\mathrm{I}_{6}$ & 194.40 & 2.59 & 17.41 & $88.07 \mathrm{a}$ & 46.48 & 94.01 & 38.93 \\
\hline & & ns & $\mathrm{ns}$ & ns & $\mathrm{LSD}_{0.05}: 5.89$ & $\mathrm{~ns}$ & $\mathrm{~ns}$ & $\mathrm{~ns}$ \\
\hline \multirow{7}{*}{2019} & $\mathrm{I}_{1}$ & 186.38 & 2.89 & 16.33 & 73.50 & 45.76 & 96.78 & 39.36 \\
\hline & $\mathrm{I}_{2}$ & 185.08 & 2.79 & 15.41 & 70.33 & 46.13 & 96.90 & 41.81 \\
\hline & $\mathrm{I}_{3}$ & 183.95 & 2.92 & 16.66 & 74.90 & 45.08 & 97.09 & 40.45 \\
\hline & $\mathrm{I}_{4}$ & 185.26 & 3.04 & 16.02 & 73.97 & 45.60 & 96.83 & 40.35 \\
\hline & $\mathrm{I}_{5}$ & 197.11 & 2.98 & 16.35 & 72.37 & 46.07 & 96.86 & 40.91 \\
\hline & $\mathrm{I}_{6}$ & 189.46 & 2.86 & 15.94 & 72.46 & 46.87 & 97.07 & 41.65 \\
\hline & & ns & ns & ns & $\mathrm{ns}$ & ns & ns & $\mathrm{ns}$ \\
\hline
\end{tabular}

*: p <0.05 düzeyinde önemli, ns: önemsiz, a,b..: LSD testi grupları. 
Çizelge 4. Deneme konularından elde edilen verim, sulama suyu (IWUE) ve su kullanım randımanı (WUE) değerleri. Table 4. The yield, irrigation water use efficiency (IWUE) and water use efficiency (WUE) values for treatments.

\begin{tabular}{|c|c|c|c|c|}
\hline Deneme yilı & Deneme konusu & Dane verimi $\left(\mathrm{kg} \mathrm{da}^{-1}\right)$ & $\begin{array}{c}\text { Sulama suyu kullanım } \\
\text { randımanı (IWUE) }\left(\mathrm{kg} \mathrm{m}^{-3}\right)\end{array}$ & $\begin{array}{l}\text { Su kullanım randımanı } \\
\text { (WUE) }\left(\mathrm{kg} \mathrm{m}^{-3}\right)\end{array}$ \\
\hline \multirow{7}{*}{2018} & $\mathrm{I}_{1}$ & $272.88 \mathrm{c}^{* *}$ & - & 0.73 \\
\hline & $\mathrm{I}_{2}$ & $294.05 \mathrm{c}$ & $4.39 \mathrm{a}^{* *}$ & 0.68 \\
\hline & $\mathrm{I}_{3}$ & $407.87 \mathrm{~b}$ & $3.04 \mathrm{~b}$ & 0.83 \\
\hline & $\mathrm{I}_{4}$ & $391.03 \mathrm{~b}$ & $1.95 \mathrm{c}$ & 0.71 \\
\hline & $\mathrm{I}_{5}$ & $474.89 \mathrm{ab}$ & $1.77 \mathrm{c}$ & 0.77 \\
\hline & $\mathrm{I}_{6}$ & $503.7 \mathrm{a}$ & $1.50 \mathrm{c}$ & 0.77 \\
\hline & & $\mathrm{LSD}_{0.01}: 88.31$ & $\mathrm{LSD}_{0.01}: 0.696$ & $\mathrm{~ns}$ \\
\hline \multirow{7}{*}{2019} & $\mathrm{I}_{1}$ & $222.49 \mathrm{c} * *$ & - & 0.80 \\
\hline & $\mathrm{I}_{2}$ & $274.94 \mathrm{bc}$ & $2.06 \mathrm{a}^{* *}$ & 0.75 \\
\hline & $\mathrm{I}_{3}$ & $335.26 \mathrm{~b}$ & $1.25 \mathrm{~b}$ & 0.70 \\
\hline & $\mathrm{I}_{4}$ & $373.14 \mathrm{~b}$ & $0.93 \mathrm{c}$ & 0.64 \\
\hline & $\mathrm{I}_{5}$ & $505.23 \mathrm{a}$ & $0.95 \mathrm{c}$ & 0.74 \\
\hline & $\mathrm{I}_{6}$ & $518.61 \mathrm{a}$ & $0.78 \mathrm{c}$ & 0.65 \\
\hline & & $\operatorname{LSD}_{0.01}: 99.09$ & $\operatorname{LSD}_{0.01}: 0.227$ & ns \\
\hline
\end{tabular}

**: p <0.01 düzeyinde önemli, ns: önemsiz, a,b..: LSD testi grupları.

verimleri denemenin birinci y1lında $474.89 \mathrm{~kg} \mathrm{da}^{-1}$ denemenin ikinci yılında ise $505.23 \mathrm{~kg} \mathrm{da}^{-1}$ olarak elde edilmiştir. Açı su yüzeyi buharlaşma değerinin \%125'inin uygulandığ $1 \mathrm{I}_{6}$ deneme konusunda ise bu değerler $503.73 \mathrm{~kg} \mathrm{da}^{-1} \mathrm{ve} 518.61 \mathrm{~kg} \mathrm{da}^{-1}$ olmuştur. Bölge ve ülke koşullarında daha önce yürütülen araştırmalarda da bitki su ihtiyacının maksimum olduğu koşullarda $(\mathrm{ETc}=\mathrm{ETm})$ elde edilen verim değerleri ile benzerlik göstermektedir (Erdem 2000; Demir ve ark. 2006; Süllü ve Dağdelen 2013; Yavuz 2016). Farklı sulama suyu uygulamaları altında deneme konularından elde edilen ayçiçeği verimleri arasındaki farklılıkları belirlemek amacıyla yapılan varyans analizi sonuçlarına göre uygulanan sulama suyu miktarları arasında istatistiksel açıdan $\mathrm{p}<0.01$ düzeyinde farklılıklar bulunmuştur. $\mathrm{Bu}$ farklılı̆g 1 belirleyebilmek için yapılan LSD testi sonuçlarına göre her iki yılda da $\mathrm{I}_{5}$ ve $\mathrm{I}_{6}$ deneme konuları en yüksek grubu oluştururken, $I_{1}$ ve $I_{2}$ deneme konuları en düşük grubu oluşturmuştur.

Deneme konularından elde edilen IWUE ve WUE değerleri Çizelge 4'de verilmiştir. IWUE değerleri denemenin ilk yılında 1.50 ile $4.39 \mathrm{~kg} \mathrm{~m}^{-3}$, denemenin ikinci yılında 0.78 ile 2.06 $\mathrm{kg} \mathrm{m}^{-3}$ arasında değişmiştir. İlk y1l elde edilen yüksek IWUE değerlerinin nedeni, deneme konularına ikinci yıla göre yüksek yağıştan dolayı daha az sulama suyu uygulanmasıdır. Araştırma sonucunda elde edilen IWUE değerleri, daha önce yürütülen çalıșmalardan elde edilen sonuçlar ile benzerlik göstermektedir. Süllü ve Dağdelen (2013) Söke koşullarında 1.00-2.36 kg m${ }^{-3}$, Yavuz (2006) Konya koşullarında $0.70-3.70 \mathrm{~kg} \mathrm{~m}^{-3}$ ve Demir ve ark. (2006), Bursa koșullarında 0.47-1.02 $\mathrm{kg} \mathrm{m}^{-3}$ IWUE değerleri elde etmişlerdir. Varyans analizi sonuçlarına göre denemenin her iki yılında da IWUE değerleri arasında istatistiksel olarak $\mathrm{p}<0.01$ düzeyinde önemli farkl1lıklar elde edilmiştir. $\mathrm{Bu}$ değerlere göre yapılan LSD testlerine göre deneme konuları arasında en az sulama suyu uygulanan $\mathrm{I}_{2}$ konusu en üst grubu oluşturmuş̧tur.

Deneme konularından elde edilen WUE değerleri denemenin ilk y1lında 0,68 ile $0.83 \mathrm{~kg} \mathrm{~m}^{-3}$, denemenin ikinci y1lında 0.64 ile $0.80 \mathrm{~kg} \mathrm{~m}^{-3}$ arasında değişmiştir. Deneme konuları arasında her iki yılda da elde edilen WUE değerleri benzerlik göstermiştir. En yüksek WUE değerleri denemenin birinci yılında $\mathrm{I}_{3}$ deneme konusundan elde edilirken, ikinci yılda $\mathrm{I}_{1}$ deneme konusundan elde edilmiştir. Araştırma sonucunda elde edilen WUE değerleri, daha önce yürütülen çalışmalardan elde edilen sonuçlar ile benzerlik göstermektedir. Süllü ve Dağdelen (2013), Söke koşullarında 0.71-1.22 kg m-3, Yavuz (2006) Konya koşullarında $0.53-0.75 \mathrm{~kg} \mathrm{~m}^{-3}$ ve Demir ve ark. (2006) Bursa koşullarında 0.60-0.78 $\mathrm{kg} \mathrm{m}^{-3}$, Karam ve ark. (2007) Lübnan koşullarında $0.83 \mathrm{~kg} \mathrm{~m}^{-3}$ WUE değerleri elde etmişlerdir. Varyans analizi sonuçlarına göre denemenin her iki yılında da WUE değerleri arasında istatistiksel olarak önemli farkl1lıklar elde edilmemiştir.

Şekil 3'den görüleceği üzere deneme konularından ölçülen bitki su tüketimi ve uygulanan sulama suyu miktarları ile elde edilen ayçiçeği dane verimleri arasında doğrusal bir ilişki bulunmaktadır. Ayrıca, her iki grafikte de elde edilen doğrusal denklemlerin istatistiksel açıdan \%1 düzeyinde önemli olduğu belirlenmiştir.

Deneme konularından ölçülen dane verimi ve bitki su tüketimlerinin Eşitlik 3'te yerine konulması ile elde edilen oransal verim azalmasına karşılık oransal bitki su tüketimi açığ 1 değerlerine göre hazırlanmış mevsimlik su-verim ilișkisi grafikleri Şekil 4'de verilmiştir. Şekilden görüleceği gibi damla sulama uygulamaları altında ayçiçeği bitkisinin mevsimlik suverim ilişkisi faktörü $\left(\mathrm{k}_{\mathrm{y}}\right)$, her iki yıl değerleri için 0.93 olarak hesaplanmıştır. Bu değerin 1'den küçük olması Doorenbos ve Kassam (1979) tarafindan belirtildiği gibi ayçiçeği bitkisinin topraktaki nem eksikliğine nispeten dayanıklı bir bitki olduğu söylenebilir. Elde edilen mevsimlik su-verim ilişkisi faktörü $\left(\mathrm{k}_{\mathrm{y}}\right)$, daha önce bölge ve ülke koşullarında yürütülen çalışmalar ile benzerlik göstermektedir. 


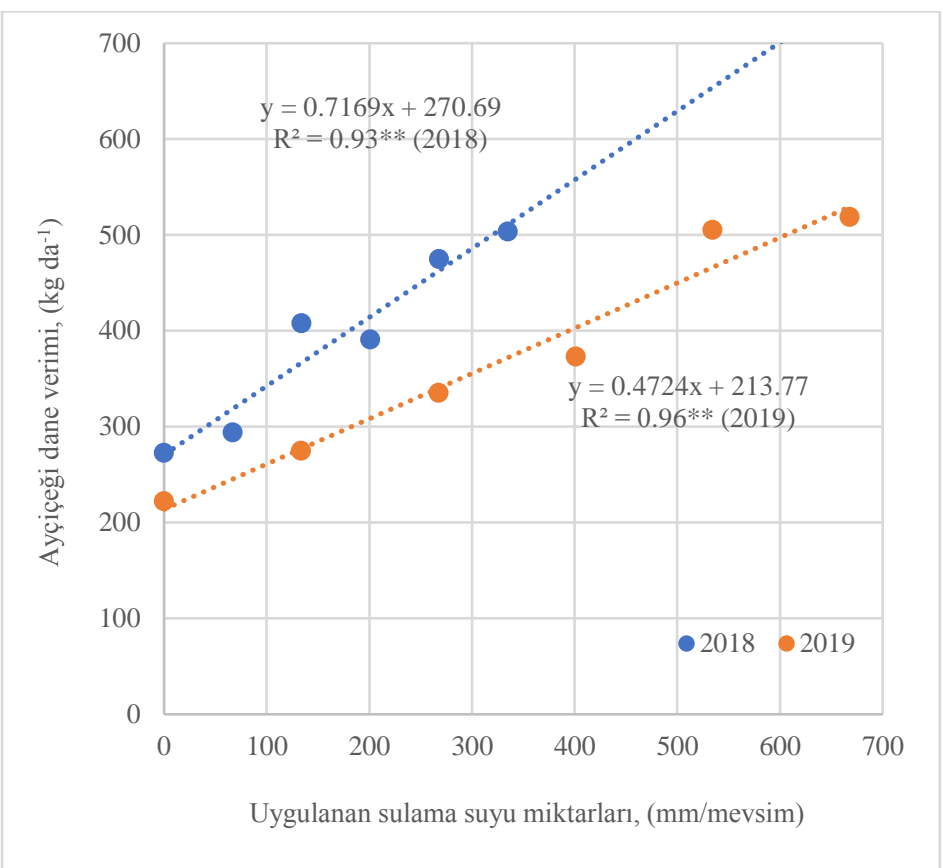

Şekil 3. Uygulanan sulama suyu -verim ilişkileri.

Figure 3. The relationhip between applied irrigation water and yield.

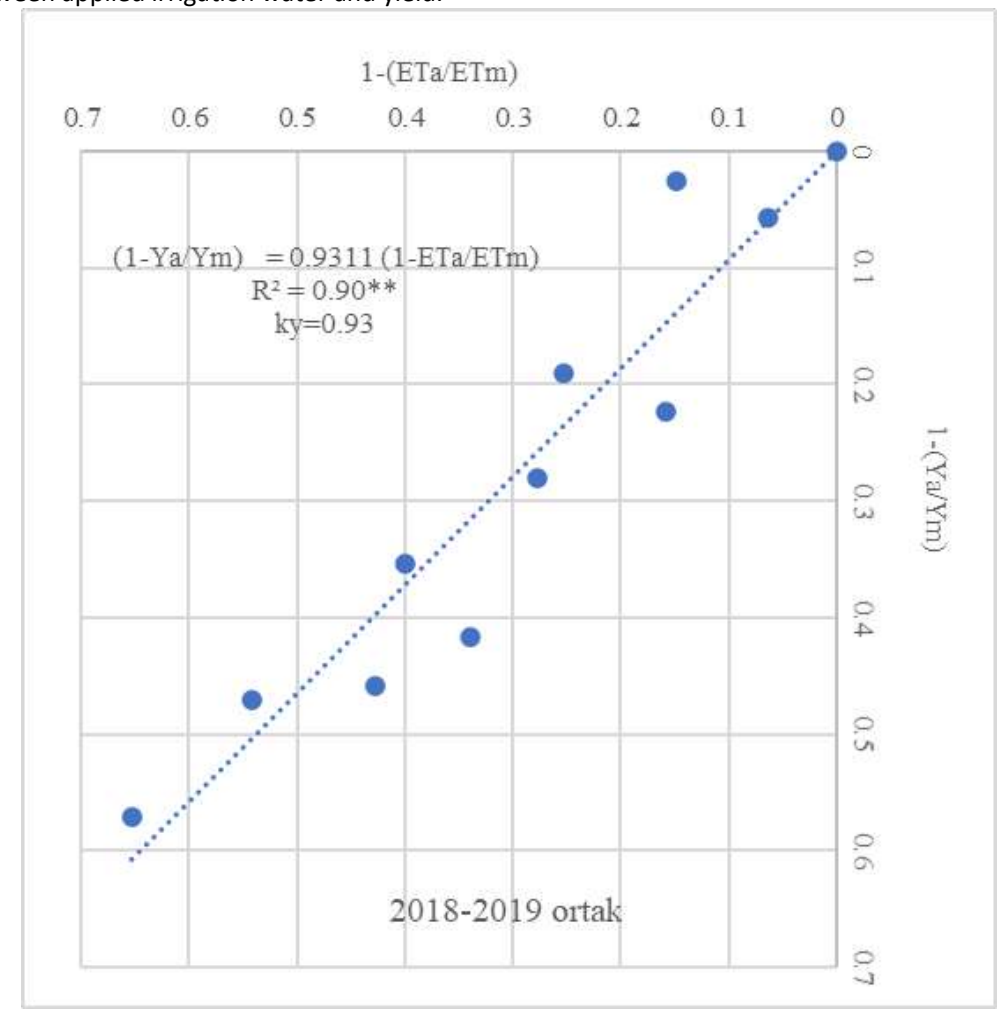

Şekil 4. Ayçiçeği mevsimlik su-verim ilişkisi grafiğgi.

Figure 4. The seasonal yield response factor for sunflower.

\section{Tartışma ve Sonuç}

Farklı sulama uygulamalarının ayçiçeği dane verimine yönelik elde edilen tüm veriler birlikte incelendiğinde, bitkinin su kısıtına karşı nispeten dayanıklı olduğu sonucu ortaya çıkmaktadır. $\mathrm{Bu}$ sonuç bölge koşullarında sadece yağışlı koşullarda yetiştirilen bitkiden ülke ortalamasına göre yüksek verimler elde edilmesini desteklemektedir. Diğer yandan sulama uygulaması ile birlikte elde edilecek ayçiçeği verimini arttırmak olasıdır. Araştırmada beş farklı sulama suyu uygulanmış ve uygulanan sulama suyu miktarı arttıkça elde edilen dane verimi artmıştır. Artan su miktarı ve elde edilen dane verimleri arasında ilişkiyi belirlemek için hesaplanan IWUE ve WUE değerlerine göre ise az sulama suyu uygulanan deneme 
konularının ön plana çıktığı görülmektedir. Bu verilerin birlikte değerlendirilmesi sonucunda, su kaynaklarının yeterli olması ve damla sulama yönteminin uygulandığı koşullarda 7 gün sulama aralığından A sınıfı buharlaşma kabından ölçülen açık su yüzeyi buharlaşma miktarının \%100 ve 125'inin uygulanması önerilebilir. Diğer yandan su kaynağının kısıtlı olduğu koşullarda yüksek IWUE ve WUE değerleri dikkate alınarak 7 gün sulama aralığında A sınıfı buharlaşma kabından ölçülen açık su yüzeyi buharlaşma miktarının $\% 25$ ve 50 'sinin uygulanması önerilebilir.

\section{Teşekkür}

$\mathrm{Bu}$ çalışma NKUBAP.03.YL.18.173 proje numarasıyla Tekirdağ Namık Kemal Üniversitesi Bilimsel Araştırma Projeleri Koordinasyon Birimi (NKÜBAP) tarafindan desteklenmiş olan yüksek lisans tezinin bir bölümüdür.

\section{Kaynaklar}

Demir A, Göksoy A, Büyükcangaz H, Turan Z, Köksal E (2006) Deficit irrigation of sunflower (Helianthus annuus L.) in a sub-humid climate. Irrigation Science 24: 279-289.

Doorenbos J, Kassam AH (1979) Yield Response to Water. FAO Irrigation and Drainage Paper No:33, Rome, Italy.

Erdem T (2000) Tekirdağ koşullarında ayçiçeğinin (Helianthus annuus L.) su-verim ilişkileri. Doktora Tezi, Trakya Üniversitesi Fen Bilimleri Enstitüsü, Tekirdağ.

Gürbüz MA (2011) Asit karakterli toprakları kireçlemenin ayçiçeği ve mısır bitkilerinin su kullanma randımanı üzerine etkileri. Doktora Tezi, Namık Kemal Üniversitesi Fen Bilimleri Enstitüsü, Tekirdağ.

Kanber R (1997) Sulama. Çukurova Üniversitesi Ziraat Fakültesi Ders Kitabı, Genel Yayın No: 174, Ders Kitapları Yayın No: 52, Adana, S. 530 .

Kanber R, Steduto P, Aydın Y, Ünlü M, Özmen S, Çetinkökü Ö, Özekici B, Diker K, Sezen MS (2004) Damla Sulama Sistemiyle Fertigasyon Uygulamalarının Antepfistığında Gelişme, Verim ve Periyodisiteye Etkisinin İncelenmesi. TÜBİTAK, TARP 1825.
Kapluhan E (2013) Türkiye'de kuraklık ve kuraklığın tarıma etkisi. Marmara Coğrafya Dergisi 27: 487-510.

Karam F, Lahoud R, Masaad R, Kabalan R, Breidi J, Chalita C, Rouphael Y (2007) Evapotranspiration, seed yield and water use efficiency of drip irrigated sunflower under full and deficit irrigation conditions. Agricultural Water Management 90: 213-223.

Korukçu A, Yıldırım O (1981) Yağmurlama Sulama Sistemlerinin Projelenmesi. Ankara: TOPRAKSU Genel Müdürlüğü Yayınları.

Sezen SM, Yazar A, Kapur B, Tekin S (2011) Comparison of drip and sprinkler irrigation strategies on sunflower seed and oil yield and quality under Mediterranean climatic conditions. Agricultural Water Management 98: 1153-1161.

Süllü A, Dağdelen N (2013) Söke ovası koşullarında II. ürün ayçiçeğinde damla sulamanın verim ve kalite üzerine etkilerinin irdelenmesi. Adnan Menderes Üniversitesi Ziraat Fakültesi Dergisi 12(2): 45-54.

Swain OS, Mohapatra P, Digal B, Sahu AP (2019) Water use efficiency of sunflower under deficit drip irrigation in east and south-east coastal plain agro-climatic zone of Odisha, India. International Journal of Current Microbiology and Applied Sciences 8: 22102216.

Walker WR, Skogerboe GV (1987) Surface Irrigation. Theory and Practice. Prentice- Hall, Englewood Cliffs, New Jersey, pp. 375.

Yavuz N (2016) Farklı sulama aralığı ve kısıtlı sulamanın, ayçiçeği verim ve kalitesi üzerine etkisi. Doktora Tezi, Selçuk Üniversitesi Fen Bilimleri Enstitüsü, Konya.

Yıldırım O (2008) Sulama Sistemlerinin Tasarımı. Ankara Üniversitesi Ziraat Fakültesi Yayınları Yayın No: 1565, Ankara.

Yurtsever N (1984) Deneysel İstatistik Metotları. Köy Hizmetleri Genel Müdürlüğü Yayınları No. 56. Ankara.

Zhang Y, Kendy E, Qiang Y, Changming L, Yanjun S, Hongyong S (1999) Effect of soil water deficit on evapotranspiration, crop yield, and water use efficiency in the North China plain. Agricultural Water Management 64: 107-122. 